\title{
СИСТЕМНЫЙ КРИЗИС В БЫВШЕЙ ЮГОСЛАВИИ: ПОСЛЕДСТВИЯ И УРОКИ
}

\author{
(C) 2020 Фадеева Инна Авенировна
}

кандидат экономических наук,

профессор кафедры английского языка факультета международной экономики

Дипломатическая академия Министерства иностранных дел Российской Федерации, Россия, Москва

E-mail: innaf576@mail.ru

В основе системного кризиса социалистической Югославии лежат прежде всего причины экономического характера. Они выражаются в постепенной утрате страной экономического суверенитета вследствие участия в кредитных отношениях, неравномерности благосостояния членов бывшей Югославии. Как показал проведенный анализ причин распада Югославии, катализатором социальных и политических противоречий в стране стала главным образом неравномерность экономического развития территорий. Регионы бывшей Югославии официально разделялись на экономически развитые (Словения, Хорватия, Сербия без Косово) и менее развитые (Босния и Герцеговины, Македония, Черногория и автономной край Косово). Сделан вывод, что ключевым уроком балканской дезинтеграции следует считать глубокие негативные экономические последствия, которые страны не могут преодолеть в течение длительного времени. Только вступление в другие интеграционные структуры может стать условием улучшения экономического положения стран.

Ключевые слова: дезинтеграция, системный кризис, Югославия, распад, уроки, последствия

Дезинтеграционные процессы в послевоенной Европе отличаются своей интенсивностью и многообразием причин, лежащих в их основе. Одним из крупнейших и значимых дезинтеграционных событий современности стал распад Социалистической Федеративной Республики Югославия. Отличительной особенностью данного дезинтеграционного процесса является его значительная временная протяженность (первое дезинтеграционное событие датировано 1991 г., а окончательный и оформленный официально распад страны пришелся на 2008 г.). Другие специфичные черты югославской дезинтеграции

Отталкиваясь от исходного положения о том, что дезинтеграционные процессы следует рассматривать широко - не только как процессы распада интеграционных структур и государств, но и в целом, как тенденции, закономерности и события, опосредующие ослабление интеграционных связей,- отметим, что распаду Югославии предшествовали глубокие экономические трансформации и системный кризис, ослабившие внутренние связи в стране и ставшие катализатором крайней формы дезинтеграции распада.

В работах авторов, изучавших проблему распада бывшей Югославии, получили осмысление преимущественно политические и социальные причины в их взаимосвязи. Такой подход действительно имеет значимые теоретико-методические основания, поскольку именно указанные группы причин стали ключевыми в югославских дезинтеграционных процессах. Тем не менее нельзя не учитывать и экономических причин, хотя и связанных тесно с политическими и социальными, но имеющих важное самостоятельное значение.

К составным элементам югославского системного кризиса, помимо политических составляющих (кризис центральной власти, межнациональных отношений, идеологический кризис), исследователи верно относят глубокий экономический кризис [5 с.155]. Согласно результатам других исследований, естественным следствием глубокого экономического кризиса в стране стал кризис политический [11 с.28].

С начала 1980-х гг., в Югославии, как и в других странах социалистического лагеря, наблюдалось снижение темпов экономического роста, индекса производства, увеличение безработицы и инфляции. Экономический оптимизм 1970-х гг. сменился пессимистичными настроениями в 1980-х гг. Не могла способствовать улучшению экономической ситуации и либерализация экономики, которая затруднялась объективными причинами, в том числе децентрализацией партийного режима и дезинтеграцией федерации. 
Характерной чертой югославской экономики являлась неравномерность экономического развития входивших в страну республик. Данное обстоятельство предопределяло различные экономические и инвестиционные потребности республик, являвшихся частью единого государства. Например, в большей степени в обновлении основного капитала нуждались Сербия и Черногория. Албания, население которой за период с 1953 по 1994 г. в абсолютных значениях выросло в 2,7 раза, не могла подкрепить демографические показатели должным экономическим обеспечением [7], что определило снижение благосостояния страны и усиление экономической неравномерности в структуре федеративного государства. Проблема экономической поляризации имела место и на национальном уровне: например, существенными были диспропорции в Македонии между развитыми и неразвитыми общинами ВВП, инвестициям и основному капиталу на душу населения.

Неравномерность экономического развития, значительная экономическая регионализация Югославии определили также факт того, что предпринятые правительством страны меры по реформированию экономики в 1989 г. оказались неэффективными. В частности, «программа оздоровления экономики», предусматривавшая принятие ряда мер в части осуществления финансовой, фискальной и социальной политики, хотя и имела некоторый успех на начальных этапах, в долгосрочном периоде не улучшила ситуацию в экономике [10].

Неравномерность экономического развития социалистической Югославии проявлялась в том, что республики и края страны официально разделялись на экономически развитые (Словения, Хорватия, Сербия без Косово) и менее развитые (Босния и Герцеговины, Македония, Черногория и автономной край Косово).

Неравномерность экономического развития - как причина югославской дезинтеграции - возникла еще в период вхождения регионов Югославии в состав Австро-Венгрии. В социалистической же Югославии данная проблема стала усугубляться, а для её решения принят закон, в соответствии с которым экономически развитые республики Югославии должны были отчислять до $2 \%$ от ВВП в фонд, средства которого в виде кредитов распределялись в пользу периферийных областей и республики страны. Со временем размеры отчислений сни- жались по инициативе развитых регионов страны, а выбранный путь дотирования регионов с низким уровнем развития стал причиной роста недовольства экономически развитых районов. Углубление экономического кризиса стало причиной обострения центробежных тенденций и регионального экономического расслоения, что в конечном итоге оказало негативное влияние на ключевые макроэкономические показатели государства [6, 8, 12].

Согласно статистическим данным, к концу 1989 г. средняя заработная плата в Словении составляла $154 \%$ по отношению к среднему уровню по Югославии, в Хорватии - 101,34\%, Boеводине $-107,32 \%$, при этом в Косово она едва превышала половину от средней $(58,98 \%)$, в Македонии составляла 68,3\% [4].

Таким образом, трудности в преодолении значительных диспропорций в экономическом развитии регионов и республик социалистической Югославии стали одной из ключевых причин системного кризиса страны. В основе балканской дезинтеграции лежал сам характер интеграционной конструкции - изначально дефектный, в основу которой было заложено множество противоречий. В этом смысле верно замечание исследователей о том, что «вся аргументация в пользу общего государства не могла скрыть его искусственного, сегментарного характера. Кроме общности исторических судеб в период раннего Средневековья славянские народы не обладали ни равным уровнем экономического развития, ни едиными политическими и правовыми системами, не имели общей культурной платформы» [9].

К значимым экономическим причинам балканской дезинтеграции следует отнести и постепенную фактическую утрату экономического суверенитета страны. Еще в социалистической Югославии полученные от западных инвесторов и крупных корпораций кредиты ограничили экономический суверенитет страны, а с конца 1960-х гг. национальная валюта была привязана к немецкой марке.

Оценка последствий системного кризиса и балканской дезинтеграции требует анализа некоторых внешнеэкономических показателей развития стран, образовавшихся на руинах Югославии: Сербии, Черногории, Хорватии, Словении, Македонии, Боснии и Герцеговины. Только двум странам бывшей Югославии - Словении (2004 г.) и Хорватии (2013 г.) - удалось 
вступить в Евросоюз. Остальные страны бывшей Югославии являются официальными кандидатами в члены ЕС или потенциальными кандидатами по текущей программе расширения. В этой связи оценку некоторых экономических показателей развития стран бывшей Югославии целесообразно вести в сравнении со средними значениями по ЕС. В таблице 1 приведены данные в динамике о соотношении уровня ВВП на душу населения в текущих ценах стран бывшей Югославии со средними значениями данного показателя в ЕС с 2000 по 2018 г. [1]

Как видно, только Словения приблизилась к среднему уровню ВВП на душу населения по ЕС. Хотя в других странах бывшей Югославии наблюдается постепенное сближение со средним уровнем экономического развития по ЕС, отставание всё ещё глубокое, что свидетельствует о том, что дезинтеграционные процессы оказали крайне деструктивное влияние на экономическое развитие стран. В этом смысле можно отметить, что и сегодня продолжается переходный экономический период в этих странах, которые очевидно, не достигли уровня экономически развитых. Собственно, в соответствии с классификацией ООН, данные страны отнесены к категории стран с переходной экономикой [3].

С точки зрения последствий дезинтеграционных процессов и их уроков для других интеграционных структур научный интерес также представляет, во-первых, степень ослабления экономических связей между бывшими членами Югославии и, во-вторых, состояние связей с другими интеграционными структурами. Индикатором, характеризующим состояние внешнеэкономических связей стран, может стать торговый баланс. В таблице 2 приведены статистические данные о состоянии торгового баланса между государствами - бывшими членами социалистической Югославии за период с 2016 по 2018 г. [2]

Как видно, состояние экономических связей стран бывшей Югославии характеризуется заметной несбалансированностью торговоэкономических отношений. Это характерно главным образом для торговли между странами с относительно слабой экономикой (Черногорией, Северной Македонией, Боснией и Герцеговоиной) и странами с более высоким уровнем развития (Словенией и Хорватией). Положительной тенденцией можно назвать постепенное снижение глубины отрицательного торгового баланса между рассматриваемыми государствами. Схожая ситуация наблюдается и в торговле между бывшими членами Югославии и странами Европейского союза. Сделанные выводы дополняются высокими значениями страновых коэффициентов несбалансированности внешней торговли между бывшими членами Югославии.

Таким образом, системный кризис и его последствия стали причиной всё ещё продолжающегося глубокого экономического кризиса в государствах - бывших членах Югославии. Страны, входившие в социалистическую Югославию не оправились от последствий дезинтеграционного шока и по сей день, что является одной из причин долгого рассмотрения кандидатур этих стран как потенциальных членов ЕС. Оценка причин системного кризиса в Югославии также позволяет сделать вывод, что в основе дезинтеграционных процессов и особенно их крайних форм, проявляющихся в виде распада интеграционной структуры, как правило, лежат заложенные при создании интеграционных структур дефекты и противоречия экономического, политического, социального характера. Предпринимаемые на уровне центральной власти меры по преодолению таких противоречий

Таблица 1. Соотношение уровня ВВП на душу населения в странах бывшей Югославии со средним уровнем ВВП на душу населения по ЕС, 2000-2018 гг., \%

\begin{tabular}{|l|c|c|c|c|c|c|c|}
\hline \multicolumn{1}{|c|}{ Страна } & 2000 & 2005 & 2010 & 2015 & 2016 & 2017 & 2018 \\
\hline Сербия & 4,8 & 12,8 & 17,0 & 17,3 & 17,8 & 18,5 & 19,8 \\
\hline Черногория & 8,9 & 12,6 & 19,8 & 20,2 & 21,7 & 23,0 & 24,2 \\
\hline Хорватия & 26,6 & 36,2 & 41,3 & 36,5 & 38,1 & 39,6 & 40,8 \\
\hline Словения & 55,9 & 62,2 & 69,7 & 64,6 & 66,7 & 69,1 & 71,4 \\
\hline Северная Македония & 10,2 & 10,4 & 13,5 & 15,0 & 15,8 & 16,0 & 16,6 \\
\hline Босния и Герцеговина & 8,0 & 10,2 & 13,7 & 14,6 & 15,4 & 15,9 & 16,6 \\
\hline
\end{tabular}

Источник: рассчитано на основе данных Всемирного Банка 
Таблица 2. Состояние торгового баланса между государствами - бывшими членами Югославии, 2016-2018 г.

\begin{tabular}{|c|c|c|c|c|c|c|}
\hline Страна & Сербия & Черногория & Хорватия & Словения & $\begin{array}{c}\text { Северная } \\
\text { Македония }\end{array}$ & $\begin{array}{c}\text { Босния и } \\
\text { Герцеговина }\end{array}$ \\
\hline \multicolumn{7}{|c|}{2016 г. } \\
\hline Сербия & - & 658,8 & 32,0 & $-92,28$ & 374,6 & 784,1 \\
\hline Черногория & $-416,1$ & - & $-120,4$ & $-34,7$ & $-24,4$ & $-94,3$ \\
\hline Хорватия & 96,8 & 150,3 & - & $-680,7$ & 44,2 & 612,9 \\
\hline Словения & 493,9 & 83,8 & 975,1 & - & 95,2 & 252,8 \\
\hline Северная Македония & $-117,3$ & 21,9 & $-12,6$ & $-72,9$ & - & 8,3 \\
\hline Босния и Герцеговина & $-570,8$ & 107,2 & $-359,1$ & $-13,2$ & $-11,5$ & - \\
\hline \multicolumn{7}{|c|}{2017 г. } \\
\hline Сербия & - & 759,4 & 85,0 & $-41,8$ & 387,8 & 779,8 \\
\hline Черногория & $-487,0$ & - & $-145,6$ & $-39,9$ & $-27,9$ & $-118,7$ \\
\hline Хорватия & 165,5 & 182,6 & - & $-936,8$ & 50,5 & 769,5 \\
\hline Словения & 470,3 & 94,9 & 1161,9 & - & 88,4 & 218,2 \\
\hline Северная Македония & $-115,8$ & 26,3 & $-17,8$ & $-81,3$ & - & 10,7 \\
\hline Босния и Герцеговина & $-541,6$ & 150,8 & $-317,0$ & 35,5 & $-5,9$ & - \\
\hline \multicolumn{7}{|c|}{2018 г. } \\
\hline Сербия & - & 834,0 & 85,3 & 11,3 & 470,9 & 839,0 \\
\hline Черногория & $-469,4$ & - & $-175,7$ & $-33,7$ & $-28,7$ & $-146,6$ \\
\hline Хорватия & 127,7 & 217,7 & - & $-1236,4$ & 49,5 & 744,8 \\
\hline Словения & 406,6 & 102,1 & 1354,0 & - & 89,7 & 239,4 \\
\hline Северная Македония & $-103,6$ & 27,911 & $-10,6$ & $-77,8$ & - & 24,4 \\
\hline Босния и Герцеговина & $-486,8$ & 209,86 & $-270,2$ & 84,2 & $-19,013$ & - \\
\hline
\end{tabular}

Источник: составлено на основе данных ЮНКТАД

не гарантируют полного прекращения дезинтеграционных процессов, а как показывает пример Югославии - они могут даже ускорить их.

Современный дезинтеграционный кризис в EC (в частности, выход Великобритании из ЕС) подтверждает, что одной из фундаментальных причин ослабления интеграционных связей и выхода участников из интеграционного объединения являются изначально дефектные ин- теграционные структуры, содержащие противоречия и невыгодные условия для участия в них. В дальнейшем можно ожидать повышение интенсивности дезинтеграционных процессов в силу экономических противоречий, которые становятся катализатором социальных и политических конфликтов, ослабляющих связи в интеграционной структуре.

\section{Библиографический список}

1. Indicators / The World Bank. URL: https://data.worldbank.org/indicator (дата обращения: 05.03.2020).

2. Trade statistics for international business development / Trade map. URL: https://www.trademap.org/(X(1) S(zxbh1w55ts35yu450bovv0e5))/Index.aspx (дата обращения: 05.03.2020).

3. World Economic Situation Prospects 2018 / UN. URL: https://www.un.org/development/desa/dpad/wp-content/ uploads/sites/45/publication/WESP2018_Full_Web-1.pdf (дата обращения: 05.03.2020).

4. Балканский кризис: народы и политика.-М., Старый сад.-1998. - 466 с.

5. Городецкая Н.Б. Югославия накануне системного кризиса (1960-1970-е) // Известия Уральского федерального университета. Серия 2: Гуманитарные науки. - 2013. - № 3 (117). - С. 155-162.

6. Демьянович Ю.Э. Этнорелигиозные противоречия в Югославии: исторический и современный контекст // Актуальные проблемы международных отношений и глобального развития: сб. науч. ст. - Вып. 6. - Минск, 2018. - C. 55-71. URL: http://elib.bsu.by/handle/123456789/214448 (дата обращения 24.02.2020) 
7. Димитров Д. Антропологический взгляд на албанский экстремизм // Албанский фактор кризиса на Балканах. Сб. науч. тр. /РАН ИНИОН.- М., 2004.- С. 105.

8. Мировая политика и международные отношения на пороге нового тысячелетия: сб. науч. ст. / Моск. обществ. науч. фонд; редкол.: М.М. Лебедева (отв. ред.) [и др.].- М., 2000.- 83 с.

9. Пономарева Е. Как была разрушена Югославия // Свободная мысль, № 3 (1639), 2013. URL: http://svom.info/ entry/361-kak-byla-razrushena-yugoslaviya/ (дата обращения: 05.03.2020).

10. Пономарева Е., Дикевич В. Крах югославской федерации. // Бизнес и политика. - 1996. - № 5(18).- С. $42-43$.

11. Пономарева Е.Г. Политическое развитие постъюгославского пространства: (внутренние и внешние факторы): монография / Е.Г. Пономарева.-М.: МГИМОУниверситет, 2007.- 235 с.

12. Тягуненко Л.В. Союзная Республика Югославия на рубеже XXI века. Природа Югославского кризиса // Новая и новейшая история. - 2001.- № 3.-С. 28-45. 